\title{
Reactive oxygen species (ROS) generation by lymphocytes in rats treated with a common food additive E407a
}

\section{Anton Tkachenko}

Biochemistry Department, Kharkiv National Medical University, Kharkiv, Ukraine

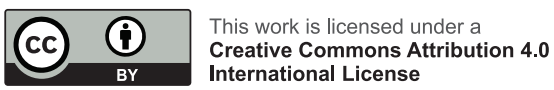

Received: 2020-02-24

Accepted: 2020-03-15

UDC: $577.114 .4: 57.084: 546.21$

\section{J Clin Med Kaz 2020; 1(55):22-26}

Corresponding author: Anton Tkachenko, $\mathrm{PhD}$ Associate Professor, Biochemistry Department, Kharkiv National Medical University, Nauky av. 4, 61022 Kharkiv, Ukraine. Tel.: +380 5010945 54; fax: +380 577004132 E-mail: antontkachenko555@gmail.com

\section{ABSTRACT}

This research deals with the evaluation of reactive oxygen species (ROS) generation in lymphocytes of rats orally exposed to a thickener and emulsifier E407a (semi-refined carrageenan). There is some evidence that E407a may be toxic and can induce intestinal inflammation. ROS generation in lymphocytes was assessed by flow cytometry using a dye $2^{\prime}, 7^{\prime}$-dichlorodihydrofluorescein diacetate (H2DCFDA) in 8 rats treated with $140 \mathrm{mg}$ of semi-refined carrageenan per $\mathrm{kg}$ of weight daily during two weeks and 8 control animals. A higher number of $\mathrm{ROS}^{\text {high }}$ viable lymphocytes were found in the group of animals exposed to E407a compared with controls. In addition, mean fluorescence intensity (MFI) in $\operatorname{ROS}^{\text {high }}$ lymphocytes was elevated, which is indicative of the intensification of ROS production by lymphocytes in response to E407a oral consumption.

Keywords: carrageenan, food additive, reactive oxygen species, lymphocytes, inflammation

\section{Е407А ТАҒАМДЫҚ ҚОСПАСЫН ПАЙДАЛАНУ КЕЗІНДЕ ЕГЕУҚҰЙРЫҚ ЛИМФОЦИТТЕРІНІН АКТИВТІ ОТТЕГІ} ТУРЛЕРІН (АОТ) ҚАЛЫПТАСТЫРУЫ

\section{А.С. Ткаченко}

Биохимия кафедрасы, Харьков ұлттық медицина университеті, Харьков, Украина

\section{ТҰЖЫРЫМДАМА}

Бұл зерттеу E407a (жартылай тазартылған каррагинан) қоюлатқышы мен эмульгаторын ауыз қуысы арқылы қолданған егеуқұйрық лимфоциттеріндегі активті оттегі түрлерін (АОT) генерациялау қарқындылығын бағалауға арналған. Кейбір зерттеулер Е407а ішектің қабынуын тудыруы мүмкін екенін көрсетті. Лимфоциттерде АОТ түзілуін екі апта бойы және дене салмағының әр килограмына 140 мг жартылай тазартылған каррагинаны қабылдайтын 8 егеуқұйрықта 2', 7'-дихлордигидрофрлуоресцеин диацетаты (H2DCFDA) бояуын пайдалана отырып, ағымдық цитометрия көмегімен және 8 бақылау жануарларында бағаланды.

Бақылаумен салыстырғанда E407a әсеріне ұшыраған жануарлар тобында жоғары мөлшерде АОТ мөлшері бар өміршең лимфоциттер санының көбеюі анықталды. Сонымен қатар, АОТ деңгейі жоғары лимфоциттердегі фрлуоресценттік орташа қарқындылық (MFI) жоғарылады, бұл E407a препаратын ауыз қуысы арқылы қабылдауға жауап ретінде лимфоциттер арқылы АОТ өндірісінің жоғарылауын көрсетеді.

Негізгі сөздер: каррагинан, тағамдық қоспалар, активті оттегі түрлері, лимфоциттер, ішектің қабынуы

\section{ГЕНЕРАЦИЯ АКТИВНЫХ ФОРМ КИСЛОРОДА (АФК) ЛИМФОЦИТАМИ КРЫС НА ФОНЕ УПОТРЕБЛЕНИЯ ПИЩЕВОЙ ДОБАВКИ Е407А}

А.С. Ткаченко

Кафедра биохимии, Харьковский национальный медицинский университет, Харьков, Украина

\section{PEЗЮME}

Данное исследование посвящено оценке интенсивности генерации активных форм кислорода (АФК) в лимфоцитах крыс, которые перорально употребляли загуститель и эмульгатор E407a (полуочищенный каррагинан). В некоторых работах показано, что Е407a может индуцировать воспаление кишечника. Образование АФК в лимфоцитах оценивали с помощью проточной цитометрии с использованием красителя 2',7'-дихлордигидрофрлуоресцеина диацетата (H2DCFDA) у 8 крыс, получавших 140 мг полуочищенного каррагинана на килограмм веса ежедневно в течение двух недель и у 8 контрольных животных. Увеличение числа жизнеспособных лимфоцитов с высоким содержанием АФК было обнаружено в группе животных, подвергшихся воздействию E407a, по сравнению с контролем. Кроме того, средняя интенсивность фрлуоресценции (MFI) в лимфоцитах с высоким уровнем АФК была увеличена, что свидетельствует об усилении продукции АФК лимфоцитами в ответ на пероральное употребление E407a.

Ключевые слова: каррагинан, пищевая добавка, активные формы кислорода, лимфоциты, воспаление кишечника 


\section{Introduction}

Marine algae have been used for decades as a source of carbohydrates such as agar, alginates and carrageenans for food industry [1]. In particular, carrageenans, which are anionic sulfated hydrocolloids of heteropolysaccharide nature made up of repeating D-galactose and 3,6-anhydrogalactose monosaccharides, are of huge importance for the market of meat and dairy products, since they show gelling, emulsifying and thickening properties [2]. Carrageenans are registered as food additives E407 and E407a and their share on the food market has been growing for years [3]. These carbohydrates obtained from seaweeds can be divided into three major types $(\lambda, \kappa$, and $\mathrm{l})$ based on the percentage of sulfated monosaccharide units and distribution of the sulfate groups [4].

Besides their nutritional application, carrageenans have been studied as antiviral, antitumor, and immunomodulatory agents $[5,6]$. Growing body of evidence suggests that these marine carbohydrates can prevent virus attachment, entry and replication [7, 8]. In addition to their efficiency demonstrated in many studies, carrageenans are characterized by cost-effectiveness and low toxicity $[9,10]$. However, it has been reported that both food-grade carrageenan and its oligosaccharide fragments used as antiviral agents are cytotoxic [11-14]. One of the mechanisms by which carrageenans may promote cytotoxicity is reactive oxygen species (ROS) generation. Bhattacharyya et al showed that carrageenan could stimulate ROS production in cell cultures of human colonic epithelial cells [15]. Furthermore, evidence from another study indicated that low-molecular-weight $\lambda$-carrageenan oligosaccharides promote ROS formation in human umbilical vein endothelial cells [16]. Barth et al demonstrated that carrageenans induced ROS generation in peritoneal neutrophils in a model of carrageenan-induced peritonitis [17]. However, the hypothesis on the pro-oxidant properties of carrageenans does not corroborate with the findings of other studies, which deny the effects of carrageenans on the cellular oxidative stress $[18,19]$. Such controversial data may be explained by misinterpretation of the results due to the confusion in terms, since different types of carrageenans (food grade, degraded carrageenan and poligeenan) have various toxicity profiles. Degraded carrageenan and poligeenan are widely recognized as toxic compounds and their use in food industry is prohibited [10].

Abe et al stated that not only phagocytic cells could act as targets for carrageenan. The food additive can also promote activation of lymphocytes [20]. Frossard et al demonstrated that orally administered $\lambda$-carrageenan caused lymphocyte anergy in mice [21]. It has been reported that semi-refined carrageenan does not promote lymphocyte apoptosis in vitro, but upregulates antiapoptotic bcl-2 protein [22]. Thus, little information concerning the features of carrageenan impact on lymphocytes both in vivo and in vitro is available.

The aim of this study was to assess ROS production by lymphocytes of rats treated with a thickener and emulsifier E407a (semi-refined carrageenan) during two weeks.

\section{Material and methods}

\section{Animals}

The animal study was approved by the Committee of Bioethics at Kharkiv National Medical University (Kharkiv, Ukraine). All procedures were performed in accordance with international and institutional guidelines, including the EU Directive 2010/63/ EU on the protection of animals used for scientific purposes and recommendations of the Council of Europe Convention for the Protection of Vertebrate Animals used for Experimental and other
Scientific Purposes (ETS123).

Sixteen female WAG rats weighing 160-190 g were provided by the vivarium. They were kept in standard conditions starting from 2 weeks prior to the beginning of the experiment. This was required for their acclimatization. The animals from the experimental group $(\mathrm{n}=8)$ were treated with E407a (140 mg/kg of weight) during 14 days on a daily basis. The control group received no semi-refined carrageenan, i.e. E407a. E407a (processed Eucheuma seaweed, PES or semi-refined carrageenan) is obtained from algae Eucheuma cottonii and Eucheuma spinosum, when they are treated at high temperature with potassium hydroxide solution. This is followed by removal of impurities by washing with alcohols. Besides carrageenan, which is the major component of the food additive, PES may contain some amounts of cellulose (EU Commission regulation No 231/2012 d.d. March 9, 2012).

\section{Measurement of spontaneous ROS in lymphocytes}

Determination of ROS production in lymphocytes was carried out by flow cytometry using a cell-permeable probe $2^{\prime}$ 7'-dichlorodihydrofluorescein diacetate (H2DCFDA). This dye can diffuse into the cells with the subsequent deacetylation by cellular esterases and its conversion into dichlorofluorescein (DCF) whose fluorescence is proportional to the amount of intracellular ROS.

Blood obtained from the animals of both groups was lysed by FACSLyse solution (Becton Dickinson, San Jose, USA) and washed twice with phosphate-buffered saline (PBS, BD, USA). Then leukocyte pellets were resuspended in PBS and stained with $\mathrm{H} 2 \mathrm{DCFDA}$ (InvitrogenTM, USA) for 30 minutes at $37^{\circ} \mathrm{C}$. The concentration of H2DCFDA in working solutions was $5 \mu \mathrm{M}$. Prior to the experiment, H2DCFDA solutions in PBS were prepared from its stock solution in DMSO (10mM). Incubation of samples with H2DCFDA occurred in the dark to avoid photooxidation of the probe. Moreover, leukocyte suspensions were incubated during 15 minutes with 7-aminoactinomycin D (7-AAD), a fluorescent dye that can bind to DNA. It is used to evaluate the integrity of cell membranes and, thus, the viability of cells. The fluorescence of DCF and 7-AAD was detected in a FACS Canto II flow cytometer (BD, USA) using the FL-1 and FL-3 channels, respectively.

The region of lymphocytes was gated based on FSC/SSC dotplots. The percentage of $\mathrm{ROS}^{\text {high }}$, 7-AAD- lymphocytes was analyzed in both groups. Then the mean fluorescence intensity (MFI) of DCF was registered. BD FACSDivaTM software was used to process the results of flow cytometry.

\section{Statistics}

The results obtained in both groups of animals were compared using Mann-Whitney U test. Values were presented as the median (Me) and interquartile range (IQR). We considered the differences statistically significant if $\mathrm{p}$ values were below 0.05 . To process numerical data, Graph Pad Prism 5.0 was used.

\section{Results}

To analyze the redox state of lymphocytes obtained from the animals treated with E407a, we used H2DCFDA. The region of lymphocytes was gated in FSC/SSC dotplots (Figure 1). Then 7-AAD cells were selected in the region of lymphocytes to analyze the fluorescence of DCF in order to exclude non-viable cells, since 7-AAD is known to be a DNA intercalator that is able to enter the cell only if its membrane integrity is compromised, which is typical for late apoptotic and necrotic cells.

Depending on DCF fluorescence, 7-AAD- lymphocytes, i.e. viable cells, were subdivided into ROS $^{\text {high }}$ and ROS ${ }^{\text {low }}$ subpopulations. We present data on flow cytometric detection of 


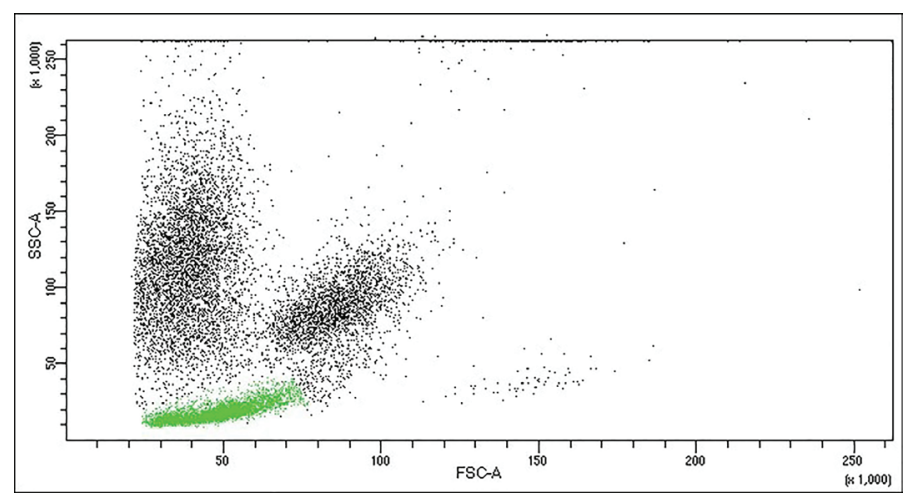

Figure 1 - Representative FSC/SSC dotplot. The region of lymphocytes was gated based on the forward and side scatters. It is highlighted in green.
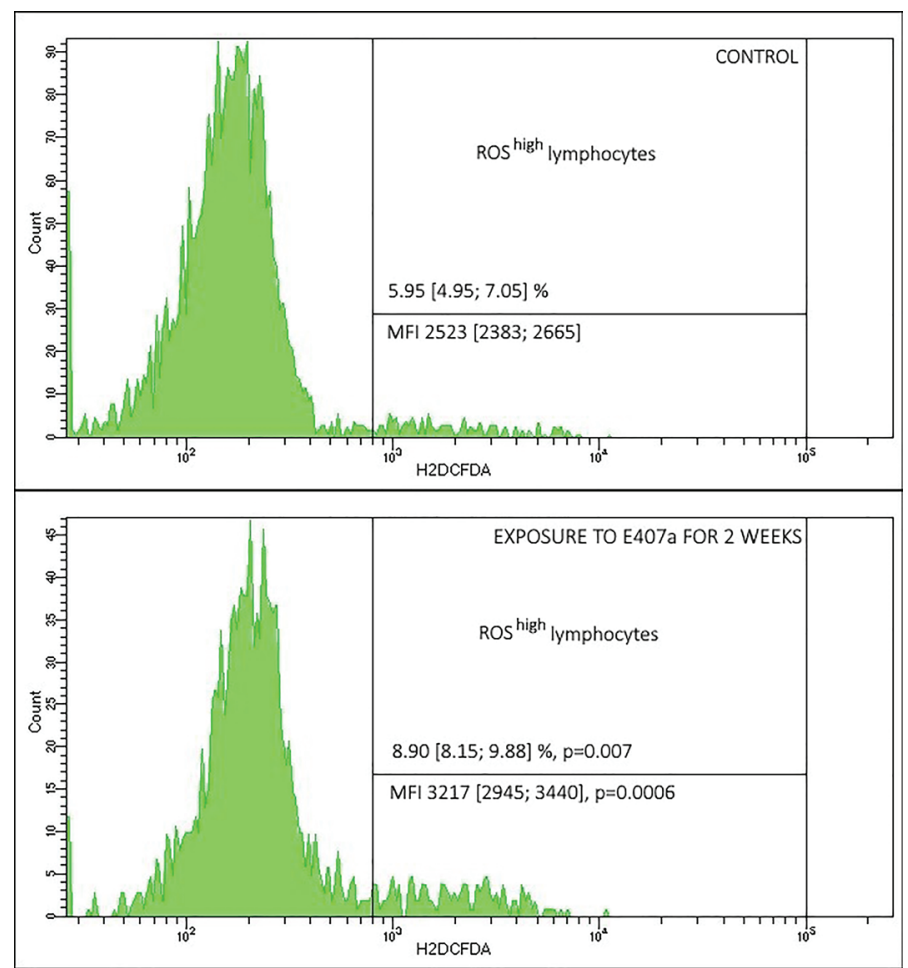

Figure 2 - Representative SSC/H2DCFDA histograms of 7-AAD- lymphocytes obtained from animals of the control (A) and experimental groups (B). Treatment of rats with E407a resulted in an increase in both the amount of ROS ${ }^{\text {high }}$ viable lymphocytes and the mean fluorescence intensity (MFI) of dichlorofluorescein (DCF) in such cells compared with controls.

ROS production in Figure 2. ROS ${ }^{\text {high }}$ and $\operatorname{ROS}^{\text {low }}$ populations are demonstrated in the corresponding histograms.

The percentage of cells in ROS high subpopulation of lymphocytes was revealed to be statistically significantly $49.6 \%$ higher in the rats exposed to E407a compared with the control group (Figure 2). Moreover, MFI of DCF was determined in ROS $^{\text {high }}$ lymphocytes to quantitatively assess ROS generation, since ROS production is proportional to DCF fluorescence in cells. When comparing MFI values, we found to be statistically significantly higher $(27.5 \%)$ in the experimental group than in controls (Figure $2)$. Thus, the increase in ROS generation was also reflected when our data were demonstrated as MFI.

\section{Discussion}

ROS are known to be produced by many types of immunocompetent cells, including lymphocytes [23,24]. Excessive
ROS generation in lymphocytes may promote the development of oxidative stress and immunosenescence [25]. The former is observed when ROS overproduction is not counterbalanced by the adequate activation of antioxidant systems. Despite the fact that canonically ROS have been believed to be cytotoxic agents inducing damage to intracellular molecules, nowadays ROS in lymphocytes are also thought to act as signaling molecules. They are involved in regulation of cytokine production, cell activation, antibody production, apoptosis, and proliferation [26, 27]. It is important to mention that the major sources of ROS in lymphocytes are NADPH oxidase and leakage of electrons from the electron transport chain $[23,26]$. Given the complex role of ROS in lymphocytes, they are important players in inflammation.

In this study, oral exposure to semi-refined carrageenan resulted in overproduction of ROS in lymphocytes. However, it is not clear whether this generation was stimulated by E407a directly or lymphocytes produced free radicals in response to pro-inflammatory cytokines. There are many reports concerning different effects of carrageenans on the redox state of cells in the body and cell cultures. There is strong evidence that carrageenan-induced inflammation is accompanied by excessive ROS generation by various types of cells and the development of oxidative stress [17,28,29]. Our current findings corroborate with such data. In addition, it is emphasized that ROS in carrageenan-induced inflammation are produced by neutrophils. In our study, it was shown that lymphocytes also contributed to this process.

Unexpectedly, many studies, including our own researches (unpublished data), have demonstrated that incubation of immune cells with carrageenan doesn't affect ROS generation [18, 19]. Furthermore, it has been shown that carrageenans have no cytototoxic effects in experiments performed using cell cultures [18]. Nor this food additive can promote apoptosis of cells even at relatively high concentrations [22].

However, carrageenans were able not only to induce ROS generation by macrophages but also to upregulate cytokines at high concentration in a dose-dependent manner [30]. ROS were also induced by carrageenans in neutrophils $[31,32]$. Thus, data on direct immunotoxic and immunomodulatory effects of carrageenans is controversial and this issue requires further thorough investigation. Our findings suggest that, apart from neutrophils and macrophages, lymphocytes are also involved in ROS generation promoted by carrageenans.

Excessive ROS synthesis by lymphocytes caused by exposure to semi-refined carrageenan may promote the release of proinflammatory cytokines, which contributes to the progression of inflammation. However, to shed a light on the role of lymphocytederived ROS in the pathogenesis of carrageenan-induced intestinal inflammation, effects of carrageenans on various mechanisms of ROS production by lymphocytes have to be scrutinized. Some evidence on the possible ability of carrageenans to magnify lipopolysaccharide (LPS)-induced ROS generation has been accumulated [32, 33]. Thus, carrageenans may make already existing intestinal inflammation more severe via intensifying bacteria-stimulated reactions.

\section{Conclusion}

A common food additive E407a can induce ROS generation by lymphocytes after oral administration. Thus, lymphocytes are involved in the mechanisms of carrageenan-induced inflammation development.

Acknowledgment. The author expresses sincere gratitude to Anatolii Onishchenko who greatly assisted the research. 


\section{References}

1. Sudha PN, Aisverya S, Nithya R, Vijayalakshmi K. Industrial applications of marine carbohydrates. Adv Food Nutr Res. 2014; 73:145-81. https://doi.org/10.1016/B978-0-12-800268-1.00008-1

2. Campo VL, Kawano DF, da Silva DB, Carvalho I. Carrageenans: Biological properties, chemical modifications and structural analysis-A review. Carbohydrate Polymers. 2009; 77(2):167-180. https://doi.org/10.1016/j.carbpol.2009.01.020

3. Hotchkiss S, Brooks M, Campbell R, Philp K, Trius A. The use of carrageenan in food. In: Pereira L (ed) Carrageenans: sources and extraction methods, molecular structure, bioactive properties and health effects, 2016, 1st edn. Nova Science Publications Inc., New York. 1-293.

4. Diogo JV, Novo SG, González MJ, Ciancia M, Bratanich AC. Antiviral activity of lambda-carrageenan prepared from red seaweed (Gigartina skottsbergii) against BoHV-1 and SuHV-1. Res Vet Sci. 2015; 98:142-4. https://doi.org/10.1016/j.rvsc.2014.11.010

5. Besednova NN, Zvyagintseva TN, Kuznetsova TA, Makarenkova ID, Smolina TP, Fedyanina LN, et al. Marine algae metabolites as promising therapeutics for the prevention and treatment of HIV/AIDS. Metabolites. 2019; 9(5):87. https://doi.org/10.3390/ metabo9050087

6. Luo M, Shao B, Nie W, Wei XW, Li YL, Wang BL, et al. Antitumor and adjuvant activity of $\lambda$-carrageenan by stimulating immune response in cancer immunotherapy. Sci Rep. 2015; 5:11062. https://doi.org/10.1038/srep11062

7. Morokutti-Kurz M, König-Schuster M, Koller C, Graf C, Graf P, Kirchoff N, et al. The intranasal application of Zanamivir and carrageenan is synergistically active against influenza a virus in the murine model. PLoS One. 2015; 10(6):e0128794. https:// doi.org/10.1371/journal.pone.0128794

8. Leibbrandt A, Meier C, König-Schuster M, Weinmüllner R, Kalthoff D, Pflugfelder B, et al. Iota-carrageenan is a potent inhibitor of influenza A virus infection. PLoS One. 2010; 5(12):e14320. https://doi.org/10.1371/journal.pone.0014320

9. Calvo GH, Cosenza VA, Sáenz DA, Navarro DA, Stortz CA, Céspedes MA, et al. Disaccharides obtained from carrageenans as potential antitumor agents. Sci Rep. 2019; 9(1):6654. https://doi.org/10.1038/s41598-019-43238-y

10. McKim JM, Willoughby JA Sr, Blakemore WR, Weiner ML. Clarifying the confusion between poligeenan, degraded carrageenan, and carrageenan: A review of the chemistry, nomenclature, and in vivo toxicology by the oral route. Crit Rev Food Sci Nutr. 2019; 59(19):3054-3073. https://doi.org/10.1080/10408398.2018.1481822

11. Tkachenko A, Marakushyn D, Kalashnyk I, Korniyenko Y, Onishchenko A, Gorbach T, et al. A study of enterocyte membranes during activation of apoptotic processes in chronic carrageenan-induced gastroenterocolitis. Med Glas (Zenica). 2018; 15(2):8792. https://doi.org/10.17392/946-18

12. Gubina-Vakyulyk GI, Gorbach TV, Tkachenko AS, Tkachenko MO. Damage and regeneration of small intestinal enterocytes under the influence of carrageenan induces chronic enteritis. Comparative Clinical Pathology. 2015; 24(6):1473-1477. https:// doi.org/10.1007/s00580-015-2102-3

13. Necas J, Bartosikova L. Carrageenan: a review. Veterinarni Medicina 2013; 58:187-205. https://doi.org/10.17221/6758VETMED

14. Tobacman JK. Review of harmful gastrointestinal effects of carrageenan in animal experiments. Environ Health Perspect. 2001; 109(10):983-994. https://doi.org/10.1289/ehp.01109983

15. Bhattacharyya S, Dudeja PK, Tobacman JK. Carrageenan-induced NFאB activation depends on distinct pathways mediated by reactive oxygen species and Hsp27 or by Bcl10. Biochimica et Biophysica Acta-General Subjects. 2008; 1780(7-8):973-982. https://doi.org/10.1016/j.bbagen.2008.03.019

16. Chen HM, Yan XJ, Mai TY, Wang F, Xu WF. Lambda-carrageenan oligosaccharides elicit reactive oxygen species production resulting in mitochondrial-dependent apoptosis in human umbilical vein endothelial cells. Int J Mol Med. 2009; 24(6):801-6. https://doi.org/10.3892/ijmm_00000295

17. Barth CR, Funchal GA, Luft C, de Oliveira JR, Porto BN, Donadio MV. Carrageenan-induced inflammation promotes ROS generation and neutrophil extracellular trap formation in a mouse model of peritonitis. Eur J Immunol. 2016; 46(4):964-70. https://doi.org/10.1002/eji.201545520

18. McKim JM Jr, Baas H, Rice GP, Willoughby JA Sr, Weiner ML, Blakemore W. Effects of carrageenan on cell permeability, cytotoxicity, and cytokine gene expression in human intestinal and hepatic cell lines. Food Chem Toxicol. 2016; 96:1-10. https:// doi.org/10.1016/j.fct.2016.07.006

19. McKim JM. Food additive carrageenan: part I: A critical review of carrageenan in vitro, studies, potential pitfalls, and implications for human health and safety. Crit. Rev. Toxicol. 2014; 40:210-243. https://doi.org/10.3109/10408444.2013.861797

20. Abe T, Kawamura H, Kawabe S, Watanabe H, Gejyo F, Abo T. Liver injury due to sequential activation of natural killer cells and natural killer T cells by carrageenan. J Hepatol. 2002; 36(5):614-23. https://doi.org/10.1016/S0168-8278(02)00022-3

21. Frossard CP, Hauser C, Eigenmann PA. Oral carrageenan induces antigen-dependent oral tolerance: prevention of anaphylaxis and induction of lymphocyte anergy in a murine model of food allergy. Pediatr Res. 2001; 49(3):417-22. https://doi. org/10.1203/00006450-200103000-00018

22. Tkachenko AS, Onishchenko AI, Lesovoy VN, Myasoedov VV. Common food additive E407a affects BCL-2 expression in lymphocytes in vitro. Studia Univ. VG, SSV. 2019; 29(4):169-76.

23. Yarosz EL, Chang $\mathrm{CH}$. The role of reactive oxygen species in regulating T cell-mediated immunity and disease. Immune Netw. 2018; 18(1):e14. https://doi.org/10.4110/in.2018.18.e14

24. Belikov AV, Schraven B, Simeoni L. T cells and reactive oxygen species. J Biomed Sci. 2015; 22:85. https://doi.org/10.1186/ s12929-015-0194-3 
25. Sizzano F, Collino S, Cominetti O, Monti D, Garagnani P, Ostan R, et al. Evaluation of lymphocyte response to the induced oxidative stress in a cohort of ageing subjects, including semisupercentenarians and their offspring. Mediators Inflamm. 2018; 2018:7109312. https://doi.org/10.1155/2018/7109312

26. Amico D, Spadoni T, Rovinelli M, Serafini M, D'Amico G, Campelli N, et al. Intracellular free radical production by peripheral blood T lymphocytes from patients with systemic sclerosis: role of NADPH oxidase and ERK1/2. Arthritis Res Ther. 2015; 17(1):68. https://doi.org/10.1186/s13075-015-0591-8

27. Bolin AP, Guerra BA, Nascimento SJ, Otton R. Changes in lymphocyte oxidant/antioxidant parameters after carbonyl and antioxidant exposure. Int Immunopharmacol. 2012; 14(4):690-7. https://doi.org/10.1016/j.intimp.2012.10.003

28. Salem S, Leghouchi E, Soulimani R, Bouayed J. Reduction of paw edema and liver oxidative stress in carrageenan-induced acute inflammation by Lobaria pulmonaria and Parmelia caperata, lichen species, in mice. Int J Vitam Nutr Res. 2019; 1-9. https://doi.org/10.1024/0300-9831/a000620

29. Di Paola R, Mazzon E, Muià C, Genovese T, Menegazzi M, Zaffini R, et al. Green tea polyphenol extract attenuates lung injury in experimental model of carrageenan-induced pleurisy in mice. Respir Res. 2005; 6(1):66. https://doi.org/10.1186/1465-99216-66

30. Yermak IM, Barabanova AO, Aminin DL, Davydova VN, Sokolova EV, Solov'eva TF, et al. Effects of structural peculiarities of carrageenans on their immunomodulatory and anticoagulant activities. Carbohydr Polym. 2012; 87:713-720. https://doi. org/10.1016/j.carbpol.2011.08.053

31. Sokolova EV, Menzorova NI, Davydova VN, Kuz'mich AS, Kravchenko AO, Mishchenko NP, et al. Effects of carrageenans on biological properties of Echinochrome. Mar Drugs. 2018; 16(11):419. https://doi.org/10.3390/md16110419

32. Sokolova EV, Karetin Y, Davydova VN, Byankina AO, Kalitnik AA, Bogdanovich LN, et al. Carrageenans effect on neutrophils alone and in combination with LPS in vitro. J Biomed Mater Res A. 2016; 104(7):1603-9. https://doi.org/10.1002/jbm.a.35693

33. Wu W, Zhen Z, Niu T, Zhu X, Gao Y, Yan J, et al. א-Carrageenan enhances lipopolysaccharide-induced interleukin-8 secretion by stimulating the Bcl10-NF- $\mathrm{BB}$ pathway in HT-29 cells and aggravates $\mathrm{C}$. freundii-induced inflammation in mice. Mediators Inflamm. 2017; 2017:8634865. https://doi.org/10.1155/2017/8634865

How to cite this article: Anton Tkachenko. Reactive oxygen species (ROS) generation by lymphocytes in rats treated with a common food additive E407a. J Clin Med Kaz. 2020; 1(55):22-26 